\title{
FORUM
}

\section{Are Eucalypts Brazil's Friend or Foe? An Entomological Viewpoint}

\author{
Jonathan D. MaJer ${ }^{1}$ AND Harry F. ReCher ${ }^{2}$ \\ ${ }^{1}$ School of Environmental Biology, Curtin University of Technology, P. O. Box U 1987, \\ Perth, WA 6845, AUSTRALIA. E mail address: imajerj@info.curtin.edu.au \\ ${ }^{2}$ School of Natural Sciences, Edith Cowan University, Joondalup, WA 6027, AUSTRALIA. \\ E mail address: h.recher@cowan.edu.au
}

An. Soc. Entomol. Brasil 28(2): 185-200 (1999)

São os Plantios de Eucaliptos Amigos ou Ameaça? Uma Visão Entomológica

RESUMO - Vastas áreas do Brasil têm sido plantadas com eucaliptos, como fontes renováveis de madeira, carvão e celulose. Apesar do rápido crescimento e da produtividade de várias espécies de eucaliptos, aliviando, sem dúvida, a pressão por madeira de áreas nativas, existem custos ecológicos que devem ser considerados. Primeiramente, algumas espécies de eucaliptos são vulneráveis ao surgimento rápido de pragas. Um grande número de lepidópteros e coleópteros nativos, assim como de formigas cortadeiras, têm-se tornado pragas em eucaliptais plantados no Brasil. Provavelmente, a diversidade de mirtáceas da América do Sul suporta uma fauna que pode adaptar-se às espécies de eucaliptos introduzidas. Uma segunda consideração é o fato de que o litter de folhas (serrapilheira) produzido sob a plantação de eucaliptos difere substancialmente daquele de florestas nativas, tanto em termos de estrutura física, quanto química, criando uma série de problemas para a fauna de decompositores. Se a diversidade de micro-artrópodes é reduzida, o ciclo de nutrientes pode ser comprometido nos plantios de eucaliptos. Terceiro, a copa de florestas nativas suporta grande diversidade e biomassa de artrópodes, da qual dependem muitos pássaros, répteis e mamíferos, como alimento. Há evidências de que a biomassa e a diversidade de invertebrados são grandemente reduzidas em copas de plantações de eucaliptos exóticos. Isto, por sua vez, reduz a base de alimento, da qual dependem artrópodes e outros animais que vivem nas florestas, comprometendo o status de sua conservação. Este trabalho revisa as evidências dos efeitos ecológicos adversos das plantações brasileiras de eucaliptos e sugere caminhos pelos quais o Brasil pode atingir suas necessidades florestais, conservando os invertebrados e vertebrados que vivem nas mesmas e das quais elas dependem.

PALAVRAS-CHAVE: Insecta, biodiversidade, conservação, monocultura, pragas.

ABSTRACT -Vast areas of Brazil are being planted to Eucalyptus in order to provide renewable sources of timber, charcoal and cellulose. Although the rapid growth and productivity of various Eucalyptus species undoubtedly relaxes the pressure on logging of native forests, there are ecological costs. Firstly, some 
eucalypt species are vulnerable to pest outbreaks. A large number of native Lepidoptera, Coleoptera and leaf-cutting ants (Atta spp.), some of which have become pests, have been found on eucalypts growing in Brazil. Probably, the diverse myrtaceous flora of South America supports a fauna that can adapt to the introduced Eucalyptus species. Secondly, the leaf litter produced under Eucalyptus plantations differs substantially from that of native forests both in terms of its physical structure and chemistry, posing a range of problems for the native decomposer fauna. If microarthropod diversity is reduced, nutrient cycling could be impeded under eucalypt plantations. Thirdly, native forest canopies support a massive diversity and biomass of arthropods on which many birds, reptiles and mammals depend for food. The evidence is that invertebrate biomass and diversity are greatly reduced in the canopies of exotic eucalypt plantations. This, in turn, reduces the food-base on which forest arthropods and other animals depend, and hence their conservation status. This paper reviews the evidence for adverse ecological effects in Brazilian eucalypt plantations and suggests ways in which Brazil might meet its forestry needs, while conserving forest invertebrates and the vertebrates that depend on them.

KEY WORDS: Insecta, biodiversity, conservation, Eucalyptus, plantations, pests.

The Atlantic rain forest of Brazil is one of the most threatened tropical ecosystems in the world (see Viana et al. 1997). It once occupied about one million square kilometres of the eastern part of Brazil, extending from Rio Grande do Norte to Rio Grande do Sul in a strip ranging from several to $160 \mathrm{~km}$ wide. Much of it has been cleared for agricultural and mineral exploitation. At the national level, less than $12 \%$ of this ecosystem remains (CIMA 1991), although this figure is as low as $1 \%$ in some States and much of it that still exists occurs as small fragments and linear strips of vegetation.

In its search for new sources of energy and cellulose, Brazil has planted massive expanses of plantations that, in terms of area planted, puts it in fourth rank throughout the world (Clemente 1996). Since many of these plantations are in areas once occupied by Atlantic rain forest, this appears to be partially redressing the problem of deforestation in this region. However, one genus of tree predominates in these plantations - the exotic Australian Eucalyptus (Myrtaceae) (Potma et al.
1976, Victor 1977). In this article, we review from an entomological perspective the evidence for ecological effects in Brazilian eucalypt plantations and suggest ways to meet Brazil's forestry needs, while conserving Brazil's forest fauna.

\section{Ecosystem Functions}

There are a number of ecosystem functions which need to operate in a self-sustaining ecosystem (Fig. 1); nutrient cycling, water cycling, soil, air and water purification, microclimate and regional climate stability and moderation are examples of important functions. Animals, particularly invertebrates, play an important role in these functions, so much so that they have been referred to as 'the little things that run the world' (Wilson 1987). The importance of invertebrates is such that they are regarded by some as the 'drivers' of ecosystems, whereas most of the vertebrates can be considered to be 'passengers' (Walker 1992). In terms of biomass, invertebrates usually exceed vertebrate animals in the 


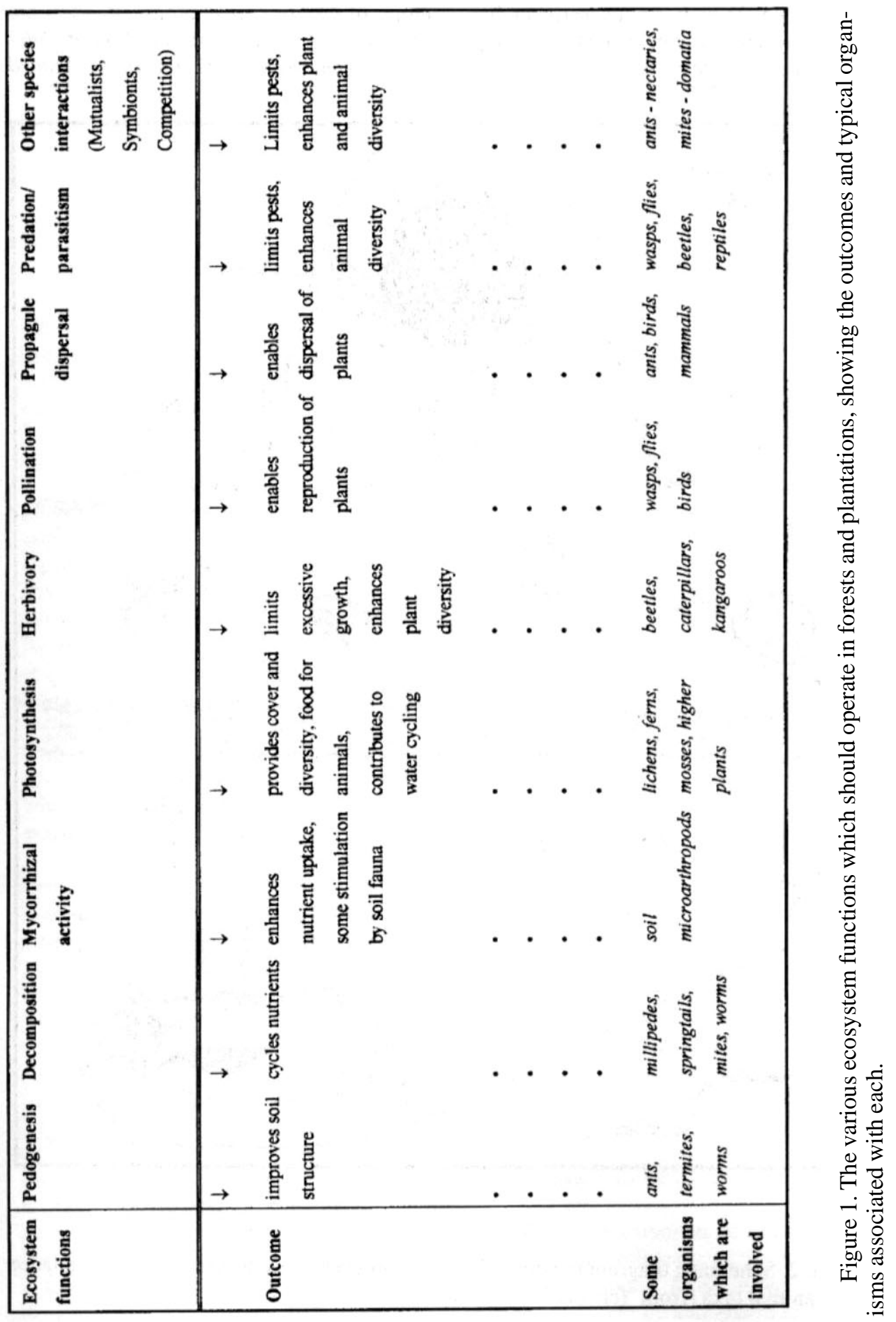


same area (Fig. 2), so it is not surprising that they play an important role in the functioning and, ultimately, the destiny and economic vi- ability of eucalypt plantations. Readers are referred to the book Animals in Primary Succession: The Role of Fauna in Reclaimed

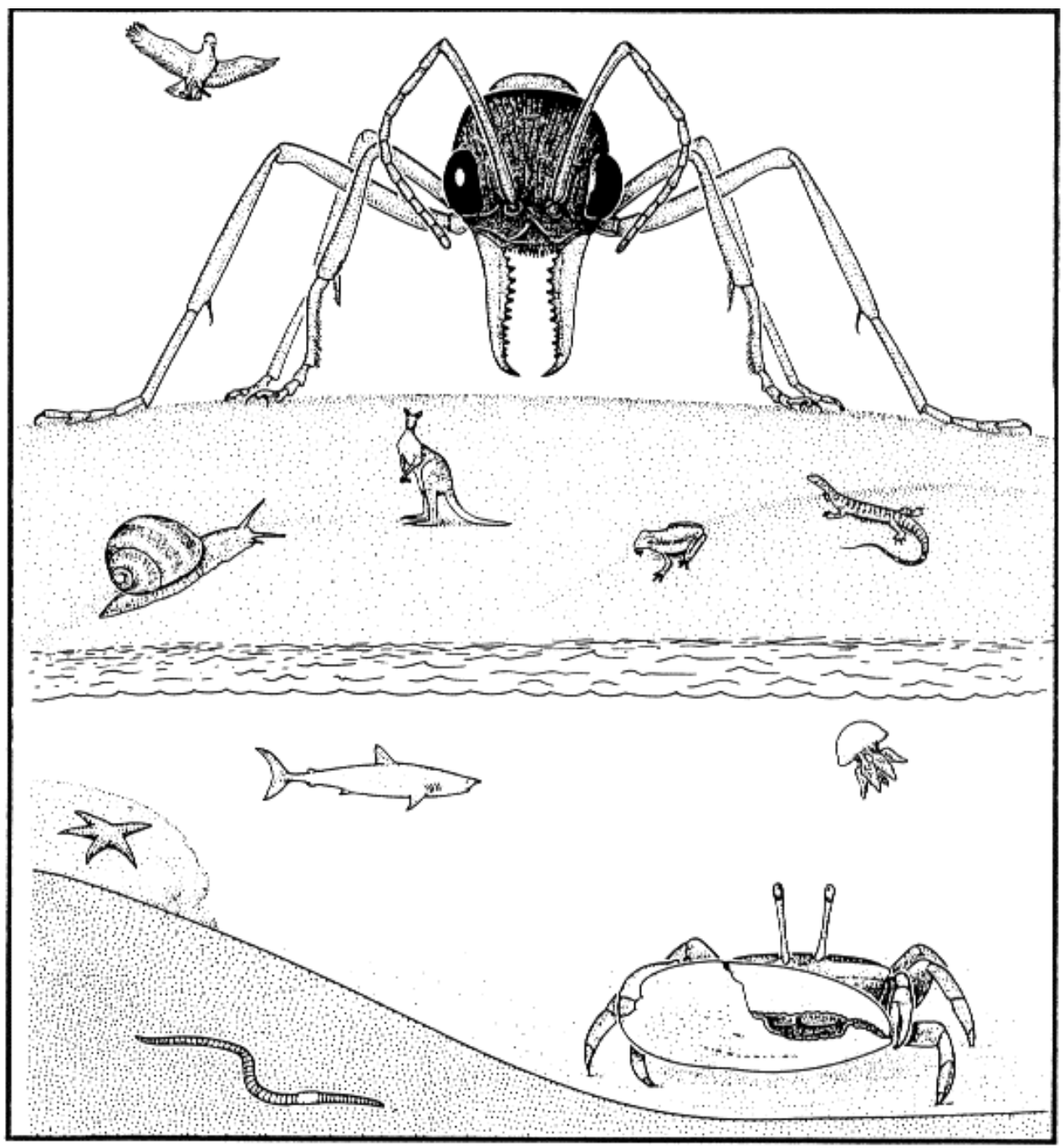

Figure 2. Schematic diagram in which size of organism represents the relative abundance of major animal taxa (from Yen and New 1997). 
Lands (Majer 1989) for a detailed account of how invertebrates can influence the outcomes of reforestation attempts.

\section{Reduction in Biodiversity}

What happens when a native forest is replaced by plantation? Essentially the complex structure of the original forest is replaced by a monoculture. The simple physical structure of plantations, the even age and size of the trees, the absence of other plant species or types, and the fact that trees used in plantations are often exotic greatly reduce the variety of habitats available to the indigenous fauna (Fig. 3). As a result of their often allelopathic effects and dense shade, plantations tend to have extremely simplified understoreys. The impact of plantation establishment on the native fauna is massive. By lacking the plant species richness and horizontal and vertical stratification of the original forest, plantations fail to provide habitat for most of the original vertebrate inhabitants (e.g., Recher, 1982, Paula 1997). Detailed studies of eucalypt plantations in Brazil (Silva 1994, 1996,1997) and in neighbouring Bolivia (Hjarsen 1997) document reductions of up to $60 \%$ of bird abundance and richness when compared with the original forest ecosystem.

These changes to biodiversity are not confined to vertebrates. Marinho et al. (1997) compared arthropods at the ordinal level beneath rain forest and a Eucalyptus grandis plantation in Brazil. Although six classes and 35 orders were sampled in the forest, there were only five classes and 27 orders under the plantation. These reductions are not confined to the ordinal level. Using ants as indicators of the general arthropod diversity, Soares et al. (in prep.) found that species richness dropped from 54 species in the original forest to 45 in the plantation. These trends are not unique to Atlantic rain forest; Oliveira et al. (1995) observed reductions from 107 species to as few as 32 ant species when Amazon rain forest was replaced by eucalypt plantations.
In addition to the implications to biodiversity of planting eucalypt plantations, to ensure ecologically sustainable production it is desirable to maintain a rich invertebrate and vertebrate fauna, containing representatives of the full range of functional groups. But in view of the fact that invertebrate faunas are so diverse, is it necessary for all of the original invertebrate species to persist in the plantation or are some of the species redundant in the ecological sense? This is a highly contentious and much-discussed issue (see Walker 1992). Ehrlich and Ehrlich (1981) have likened the situation to rivets on an aeroplane - maybe there is no problem if one or even a few are lost, but there comes a point when so many are missing that the plane crashes. The resilience of an ecosystem, such as a plantation, may similarly be affected by an absence of species, but at what point does this reach problematic levels? Walker's (1992) paper on Biodiversity and ecological redundancy was understood by some to suggest that in those functional groups where there was some redundancy (i.e., the existence of more than one ecologically equivalent species), we could afford to lose some of its members. Walker (1995) subsequently clarified this misunderstanding by pointing out that where one of the member species declines or disappears for some reason, ecological equivalence allows compensation by other species that are not so affected. In cases where species in a functional group are virtually equivalent, they probably differ in their environmental adaptations and thus are each able to compensate for species loss under different sets of environmental conditions. Walker (1995) therefore concluded that no species could be considered as 'functionally redundant': a cautious manager will therefore conserve all, or as many species as possible.

\section{Changes in Ecosystem Functioning}

Are there examples of plantations being affected by declines or alterations in the invertebrate fauna? Most studies which have linked invertebrate abundance or diversity to 

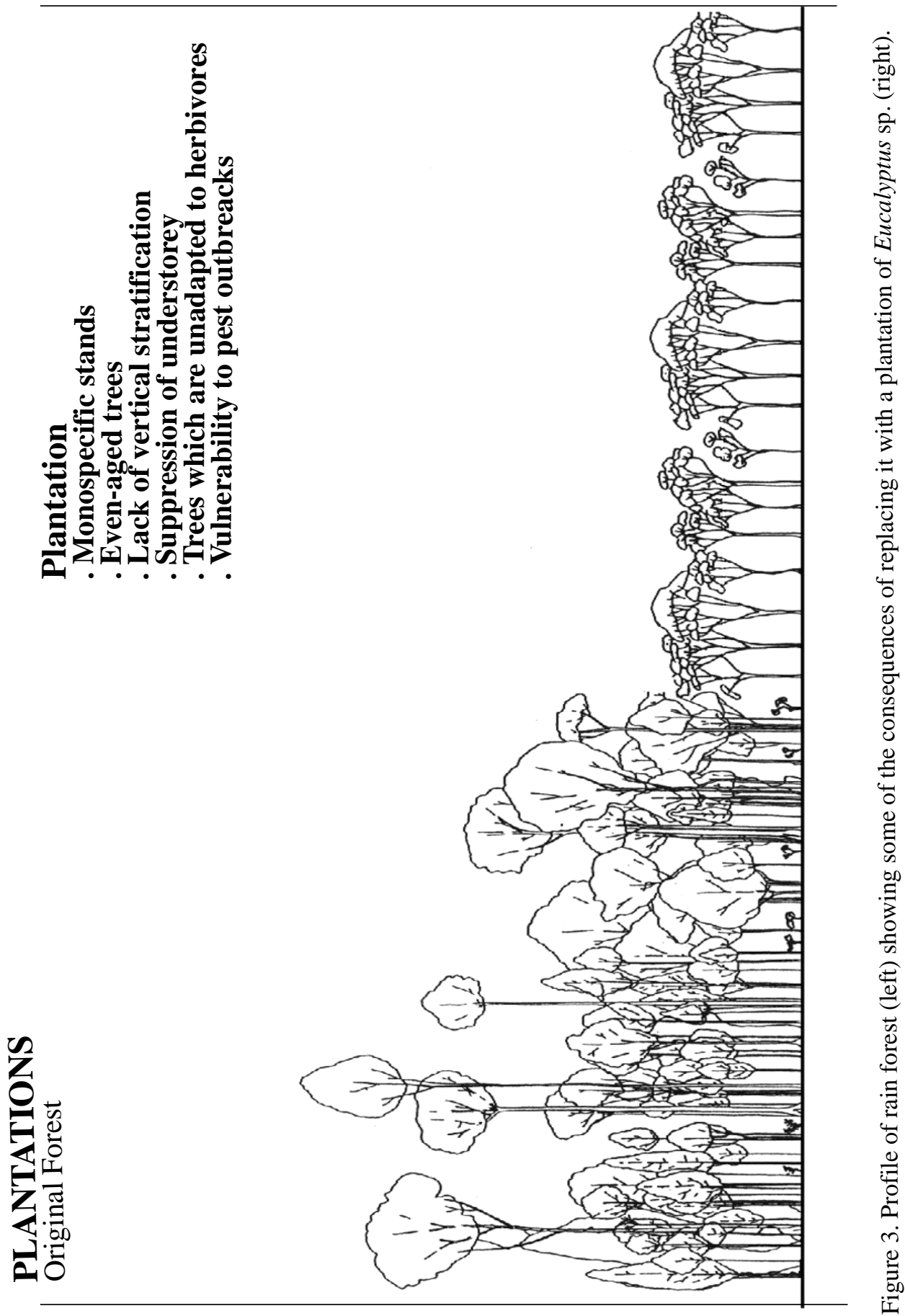
ecosystem functioning have been inferential (see Noss 1990, Aronson et al. 1993) and have assumed that animal abundance in a particular feeding guild indicates their degree of contribution to ecosystem function (e.g., Williams 1993). It does not prove, however, that a particular function will not operate or will be enhanced if a particular group of animals is absent or abundant.

Demonstration projects are required which link invertebrate groups with ecosystem functioning, and which show how the abundance and/or activity of such animals may be encouraged. Researchers tend to avoid this approach because of the difficulties in demonstrating causal links (Lamont 1995). Manipulations involving deletion or addition of species (e.g., Naem et al. 1995), or alterations in their abundances, are necessary to describe their role with complete confidence; Lamont (1995) has outlined test procedures that might be adopted.

Notwithstanding these interpretational problems, there is evidence that plantations have great potential to produce undesirable changes in the invertebrate fauna, with consequent changes in ecosystem functioning. Below, we outline three aspects of ecosystem functioning that might be affected by the establishment of eucalypt plantations.

\section{Example 1 - Threats to Pollination}

Pollination is an important ecosystem function as it provides a crucial step in the perpetuation of plant species through sexual reproduction. It is desirable to maintain pollination relationships in plantations to produce self-sustaining plant populations within the understorey and the adjacent ecosystems. Tepedino (1979) has estimated that $67 \%$ of flowering plants rely upon insects for their pollination. The role of insects as pollinators therefore seems to be of critical importance, but the effect of pollinator limitation at a community scale has rarely been studied and conclusions remain largely inferential (Whelan 1989). Recent reviews by Rathcke and Jules (1993) and Kearns and Inouye (1997) docu- ment the relationship between insects and the persistence and resilience of a plant community through the process of pollination.

Pollination interactions are vulnerable to many disturbances related to ecosystem fragmentation and alteration (Kearns \& Inouye 1997), and may therefore provide good models for the role of invertebrates in ecosystem functions. There are very few studies of pollination dynamics in plantations. However, several trends apparent from studies in fragmented and isolated habitats are relevant, since plantations exhibit some of the features of fragments. Furthermore, plantation establishment often results in the fragmentation of the original ecosystem in the area.

Insect pollinator diversity and abundance have been found to decline with decreasing habitat area and increasing isolation (Jennersten 1988, Aizen \& Feinsinger 1994a). These studies, and others (e.g., Aizen \& Feinsinger 1994b, Buchmann \& Nabhan 1996), have found a corresponding decline in seed set with increasing fragmentation of habitat. Plants relying on one, or a few types of pollinators, suffer lower seed set in small isolated populations if the pollinators disappear and fail to return (Jennersten 1988, Houston et al. 1993, Pavlik et al. 1993).

Generalisation of pollination systems may buffer both plants and pollinators (Bond 1994, Waser et al. 1996), but they are open to exploitation by super-generalists such as the honey bee, Apis mellifera L. Honey bees are not native to Brazil, but are frequently introduced into eucalypt plantations where there is a good source of nectar (Pirani \& Cortopassi-Laurino 1993). Australian and American research has shown that honeybees compete with native insects and birds for nectar and nesting sites (see Eikwort \& Ginsberg 1980, Roubik 1991, Paton 1996). In some circumstances, competition with this bee is detrimental to native bee abundance and diversity, and may lead to lowered seed set of some plants (Aizen \& Feinsinger 1994a, Paton 1996). Generalised pollination systems can ultimately lead to the exclusion of locally rare plant species from the community through 
competition for shared pollinators (Waser 1978).

Cascade effects, in which the loss of one partner in a mutualistic relationship indirectly affects other species in the community, may follow pollination disruptions, particularly if the partner lost is a keystone species (Lambeck 1992). Janzen (1974) has recorded such a situation in Central American tropical forests. Male euglossine bees in these forests are highly specific to orchid species, but the females rely on a variety of scattered woody plants for nectar. Habitat clearing and development has led to a decline in bee habitat and numbers, fewer native woody plants, the use of weedy species in clearings by the female bees, and reduced visits to the more widely scattered native woody plants. The fate of the bees, orchids and native woody plants are thus all intimately connected. Cascade effects obviously have great potential to affect areas where plantations have been established and which may suffer pressures such as isolation, colonisation by exotic plant and animal species, altered community structure and loss of suitable nesting sites. The fact that more cases like this have not been documented probably reflects our poor understanding of pollinator dynamics at different spatial and temporal scales, and time-lags between the disappearance of pollinators and its effects on the community (Bond 1994).

\section{Example 2 - Threats to Nutrient Cycling}

Studies of soil invertebrates in Eucalyptus plantations in southern China found 25 invertebrate groups (at the ordinal level) in fenced eucalypt plantations in which litter was allowed to accumulate and 11 groups in unfenced eucalypt plantations where litter was collected for fuel. This compared with 27 and 31 groups collected in natural secondary forest and broadleaf mixed forest plantation respectively. The biomass of soil invertebrates in the natural forest and the mixed broadleaf plantation was double that of the protected eucalypt plantation and six times greater than the invertebrate biomass of the eucalypt plan- tation without litter (Liao et al. 1984).

Plantations are also known to produce negative effects on litter decomposition in Brazil (Schoereder et al. 1990). A detailed study of litter fauna density and decomposition of rain forest litter in rain forest versus Eucalyptus litter under plantation revealed considerably lower densities of Acarina and Collembola in the latter habitat and concomitant reductions in the rate of litter decomposition (Louzada J. N. C. et al. unpublished). The authors linked this reduction in decomposition to the impoverished litter fauna in the plantation which, in turn, was believed to result from the inferior and homogenous chemical composition of the litter and the harsher microclimate beneath the plantation (Vallejo et al. 1987).

These results give reason for concern, since Eucalyptus plantations are notoriously dependent on high nutrient inputs (Paula 1997). If plantations that are more economical in nutrient usage and cycling were encouraged, financial savings could be made and nutrient runoff into nearby water-courses would be minimised.

\section{Example 3 - Reduced Food for Insectivorous Vertebrates}

One trend that emerges from our own studies in native Eucalyptus ecosystems within Australia is the link between the biodiversity of arthropod communities of the canopy and site fertility (Recher et al. 1996). On the basis of the data from eucalypt forests, the most abundant and richest arthropod communities have been found to occur in habitats with high foliar nutrient levels (Table 1). On an individual plant the species richness of arthropods may be determined by the structural complexity of the plant (e.g., leaf and bark characteristics), its biochemical defences against insect attack, and by foliage nutrient levels, which in turn are an index of plant production (Table 1). There is also evidence that foliar nutrients are related to site fertility (Recher et al. 1996) (Table 1), although this relationship does not always hold. This relationship can 
Table 1. Relationship between soil nutrients, foliar nutrients, arthropod abundance and arthropod species richness on Grey Box (E.moluccana), Narrow-leaved Ironbark (E.crebra), Jarrah (E.marginata) and Marri (E.calophylla) at Scheyville, NSW, Australia and Karragullen, WA , Australia. Note how percentage tree use by birds tends to reflect arthropod loads on foliage rather than percentage contribution of tree species to the total canopy (adapted from Recher et al. 1996).

\begin{tabular}{|c|c|c|c|c|}
\hline & \multicolumn{2}{|c|}{ New South Wales } & \multicolumn{2}{|c|}{ Western Australia } \\
\hline Soil nitrogen $\left(\mu \mathrm{g} \mathrm{g}^{-1}\right)$ & \multicolumn{2}{|c|}{2168} & \multicolumn{2}{|c|}{860} \\
\hline Soil phosphorus $\left(\mu \mathrm{g} \mathrm{g}^{-1}\right)$ & \multicolumn{2}{|c|}{1149} & \multicolumn{2}{|c|}{660} \\
\hline \multirow[t]{2}{*}{ Soil potassium $\left(\mu \mathrm{g} \mathrm{g}^{-1}\right)$} & \multicolumn{2}{|c|}{2535} & \multicolumn{2}{|c|}{76} \\
\hline & Box & Ironbark & Jarrah & Marri \\
\hline Foliar nitrogen $\left(\mathrm{mg} \mathrm{g}^{-1}\right)$ & 10.2 & 13.7 & 7.9 & 10.0 \\
\hline Foliar phosphorus $\left(\mathrm{mg} \mathrm{g}^{-1}\right)$ & 0.5 & 0.9 & 0.3 & 0.5 \\
\hline Foliar potassium $\left(\mathrm{mg} \mathrm{g}^{-1}\right)$ & 3.4 & 3.9 & 3.7 & 5.7 \\
\hline Mean arthropod individuals per tree & 411 & 760 & 242 & 253 \\
\hline Total arthropod species on all trees & 642 & 727 & 446 & 443 \\
\hline (both tree species) & \multicolumn{2}{|c|}{974} & \multicolumn{2}{|c|}{581} \\
\hline Percentage canopy & 56 & 44 & 89 & 11 \\
\hline \multicolumn{5}{|l|}{ Percentage tree use by: } \\
\hline eastern Thornbill birds & 27 & 73 & - & - \\
\hline western Thornbill birds & - & - & 75 & 25 \\
\hline No. of nesting bird species & \multicolumn{2}{|c|}{66} & \multicolumn{2}{|c|}{36} \\
\hline
\end{tabular}

have a follow-on effect to the insectivorous avifauna. For instance, our data on insectivorous thornbills (Table 1) suggest that bird usage of trees reflects the invertebrate loads which those tree species support. A similar response has been suggested in relation to some arboreal marsupials occurring in southern Australia (Braithwaite et al. 1983, Cork \& Catling 1996).

Importation of plants into new areas leads to an association with arthropods that have little or no adaptation to feed upon that species. The result is that these trees tend to be barren of arthropods, which themselves are food resources for much of the vertebrate fauna. This, and the absence of structural and floristic diversity, shelter, and limited nesting or denning sites, explains why plantations can sustain only a small proportion of the original forest vertebrate fauna (Recher 1982).

\section{Pest Outbreaks}

An additional problem that threatens plantations is their vulnerability to pest outbreaks (Recher 1982, Schowalter \& Means 1988). This can result from their lack of evolved defence to particular herbivores or to the paucity of beneficial limiting agents. Species of arthropods native to eucalypt forests and woodlands in Australia have become pests on eucalypts planted in other countries. These include Paropsis charybdis Stal (Coleoptera: Chrysomelidae) in New Zealand, the eucalyptus snout beetle Gonipterus scutellatus (Gyllenhal) (Coleoptera: Curculionidae) in New Zealand, the African continent, Madagascar and Mauritius, and Phoracantha semipunctata (Fabricius) (Coleoptera: Cerambycidae) in the Ethiopian, Madagascan, Palaearctic and Neotropical regions (Carne \& 
Taylor 1978). Indigenous arthropods can also attack eucalypt plantations. In Brazil large tracts of Eucalyptus have been defoliated by native Lepidoptera (Zanúncio 1993, PedrosaMacedo 1993, Fagundes et al. 1996), Coleoptera (Zanúncio et al. 1993, PedrosaMacedo 1993) and also leaf-cutting ants (Atta and Acromyrmex spp.) (Vilela 1986, Anjos et al. 1993), some of which have become significant pests. In addition to this, mortality of young trees due to termite attack is substantial in eucalypt plantations in Africa (involving termites of the subfamily Macrotermitinae, a group not present in Australia), Asia and South America (Harris 1971), although the impacts on mature trees are generally less severe. Termites that attack eucalypts and other timbers in Brazil are documented in Berti Filho (1993). So significant are some of the pests of eucalypt plantations in Brazil, that many student dissertations have been generated (e.g., Macedo 1975, Berti Filho 1981, Barros 1984, Dietrich 1989, Pereira 1992).

What are the reasons for, and implications of, this diverse complex of pests in Brazilian eucalypt plantations? Possibly the diverse myrtaceous flora of South America supports a fauna which can readily adapt to introduced Eucalyptus species. The result is destruction of those features of the plantation that provide habitat for local fauna. This is compounded by the fact that the agrotoxins used to combat such pests (e.g., "Mirex" for leafcutter ants) can impact on the local wildlife and cause deleterious effects in the environment (Paula 1997).

The insects that are pests in these plantations are generally not abundant or pestiferous in the adjoining native vegetation. It is only when forest is converted to a monoculture that pests such as leaf-cutter ants become a problem (Bento \& Della Lucia 1993). Indeed, when fragments of forest are left within the matrix of plantation, the frequency of Atta spp. is lower (Soares S. M. et al. unpublished).

\section{Other Threats}

We now discuss two other threats that have immense capacity to detrimentally alter the diversity and functioning of invertebrates in areas where plantations have been established. Fire is an important natural disturbance in forests. Almost all dry forests and many moister types burn at intervals. Natural fire frequencies in Australia and North America, where there has been extensive research on fire histories, indicate average fire frequencies in dry forests of three to four burns per 100 years. Intervals between natural fires can range from less than five years to greater than four or five hundred years according to forest type, topography, human interference and chance. The area of forest burnt in any one fire can also vary substantially from a few hectares to tens of thousands of hectares, again according to conditions and chance circumstances. Outside of the wet tropics, forests are a mosaic of burns; in a very real sense, fire imposes a second order of pattern on the mosaic of forest types determined by topography and edaphic conditions.

Now people have greatly altered natural fire regimes, either by suppressing forest fires or by using fire as a tool to clear forest. The latter may be carried out to remove understorey vegetation, to foster the development of grass within the forest for grazing stock, or as a means of reducing fuel loads to prevent wildfires from developing. These changes in fire regime have significant effects on forest biodiversity and in all cases change the composition and structure of the forest vegetation. These changes disadvantage plants and animals that require long intervals between burns and favour plants and animals that require more open, and usually drier and warmer forest environments. The net effect of too frequent fires, regardless of fire intensity or fire season, is to simplify forest environments and reduce forest biodiversity.

Moist forests, such as rainforest, do not experience fire under natural conditions, although the sclerophyllous nature of the $\mathrm{Eu}$ calyptus plantations means that they can, and do, burn, with fires spreading into ecosystems outside of the plantation. The plant species in the understorey of the plantation and in the 
adjoining forests are generally susceptible to fire and are often killed by burning. The result is an area of dead shrubs and trees, where only some of the hardy or larger trees survive. Many of the understorey plants are also killed, resulting in the ground being invaded by grasses and fast-growing pioneer shrubs - the area seldom reverts back to rainforest. Accompanying the changes in vegetation are changes in microclimate. Unlike in cool humid rain forest, the area becomes hot and dry, a change which has negative feedback effects on the surviving or recolonizing biota. The impact of fire on fauna in fire-susceptible forests is unequivocal, although it may be difficult to unravel the effects of clearing or degradation of the forest from that of the burn. Whichever is the case, the invertebrate and vertebrate communities of the burnt areas are changed and commonly simplified.

Fragmentation of the forest by establishment of plantations further jeopardises the conservation status of forest fauna. In addition to the loss of habitat, many invertebrates are adversely affected by edge effects (Didham 1997) that, for different groups of animals, extend to varying distances into the forest, and by the general degradation of these small and vulnerable areas of forest (see Harris 1984, Saunders et al. 1987, 1991, Hunter 1990, Saunders \& Hobbs 1991, Noss 1996, Majer et al. in press). Edge effects include the intrusion of weeds and open country animals that compete with or prey on the forest biota.

Thus, in addition to the area of habitat lost to plantation establishment, we should factor in the degradation and changes in fauna composition that occur in forests adjacent to these areas.

\section{Reducing the Problem}

This review has shown that eucalypt plantations can pose a considerable threat to biodiversity, to the quality of the environment and, through losses to pests, to the economic viability of the program. Establishment of fast-growing plantations is undoubtedly one way of relaxing the pressure on native forests for timber exploitation so, in this sense, these plantations are beneficial. However, for the reasons mentioned, plantations should be of native trees wherever possible and should only be planted on already degraded or cleared land to avoid clearing existing forests. If the plantations are within the forest matrix, they should be planned to allow for wildlife corridors between blocks of native forest and should not be planted to the extent that the amount of native forest remaining becomes minimal.

Plantations should complement, not replace, natural forests. They should reduce pressures on natural forests (Forest Stewardship Council 1993) but equally, every effort should be made to conserve or use in an ecologically sustainable way (Sizer 1994), the areas of Atlantic rain forest which remain.

\section{Literature Cited}

Aizen, M. A. \& P. Feinsinger. 1994a. Habitat fragmentation, native insect pollinators, and feral honey bees in Argentine Chaco Serrano. Ecol. Appl. 4: 378-492.

Aizen, M. A. \& P. Feinsinger. 1994b. Forest fragmentation, pollination, and plant reproduction in a chaco dry forest, Argentina. Ecology 75: 330-351.

Anjos, N., D. D. O Moreira, \& T. M. C. Della Lucia. 1993. Manejo integrado de formigas cortadeiras em reflorestamentos, p. 212 - 241. In T. M. C. Della Lucia (ed.). As formigas cortadeiras. Ed. Folha de Viçosa, Viçosa, 212 p.

Aronson, J., C. Floret, E.C. Le Floc'h, C. Ovalle \& R. Pontanier. 1993. Restoration and rehabilitation of degraded ecosystems in arid and semiarid regions. I. A view from the South. Restor. Ecol. 1: 8-17.

Barros, M. E. P. 1984. Análise faunística das comunidades de lepidópteros desfo- 
lhadores de eucalipto em regiões do Maranhão, Bahia, Espírito Santo e São Paulo. MSc thesis, Universidade Federal de Viçosa, Viçosa, 63 p.

Bento, J. M. S. \& T. M. C Della Lucia. 1993. Acabar com a saúva sem acabar com o Brasil. Ciência Hoje 15: 48-49.

Berti Filho, E. 1981. Insetos associados a plantações de espécies do gênero Eucalyptus nos estados da Bahia, Espírito Santo, Mato Grosso do Sul, Minas Gerais e São Paulo. Docencia thesis. Universidade de São Paulo, Piracicaba, $176 \mathrm{p}$.

Berti Filho, E. 1993. Manual de pragas em florestas. 3. Cupins ou térmitas. IPEF/SIF, Viçosa,56 p.

Bond, W. J. 1994. Do mutualisms matter? Assessing the impact of pollinator and disperser disruption on plant extinction. Phil. Trans. Royal Soc., B London Biol. Sc. 344: 83-90.

Braithwaite, L. W., M. L. Dudzinski \& J. Turner. 1983. Studies on the arboreal marsupial fauna of eucalypt forests being harvested for woodpulp at Eden, New South Wales. II. Relationship between fauna densities, richness and diversity, and measured variables of habitat. Austral. Wildlife Res. 10: 231-247.

Buchmann, S. L. \& G. P. Nabhan. 1996. The forgotten pollinators. Washington (DC): Island Press.

Carne, P. B \& K.L. Taylor. 1978. Insect pests, p. 155-168. In W. E. Hillis and A. G. Brown (eds.). Eucalypts for wood production. Adelaide, CSIRO.

CIMA - Comissão Internacional para a Preparação da Conferência das Nações Unidas sobre Meio Ambiente e Desenvolvimento. 1991. Subsídios
Técnicos para Elaboração do Relatório Nacional do Brasil para a CNUMAD. Conferência das Nações Unidas sobre Meio Ambiente e Desenvolvimento. Brasília, DF. 168p.

Clemente, A. M. 1996. Atualidades: Potência florestal. Silvicultura 1: 10-13.

Cork, S. J. \& P.C. Catling. 1996. Modelling distributions of arboreal and grounddwelling mammals in relation to climate, nutrients, plant chemical defences and vegetation structure in the eucalypt forests of southeastern Austral. Forest Ecol. Manage. 85: 163-176.

Didham, R. K. 1997. The influence of edge effects and forest fragmentation on leaf litter invertebrates in Central Amazonia, p 55-70. In. W. F. Laurence and R. O. Bierregaard (eds.). Tropical Forest Remnants: Ecology, Management, and Conservation of Fragmented Communities. Chicago,University of Chicago Press.

Dietrich, C. R. R. C. 1989. Ocorrência de cupins (Insecta: Isoptera) em reflorestamento de Eucalyptus spp., MSc thesis. Universidade de São Paulo, Piracicaba, 68 p.

Ehrlich, P. R. \& A H. Ehrlich. 1981. Extinction: The Causes and Consequences of the Disappearance of Species. New York: Random House.

Eikwort, G. C. \& J.M.F. Gisberg. 1980. Foraging and mating behaviour in Apoidea. Ann. Ver. Entomol. 25: 421446.

Fagundes, M., J.C. Zanúncio, F.S. Lopes \& P. Marco Jr. 1996. Comunidades de Lepidópteros noturnos desfolhadores de eucalipto em três regiões do cerrado de Minas Gerais. Rev. Bras. Zool. 13: 763 771 . 
Forest Stewardship Council (FSC) 1994. What is the Forest Stewardship Council?. Oaxaca, Mexico, Forest Stewardship Council.

Harris, L. D. 1984. The fragmented forest, island biogeography theory and the preservation of biotic diversity. Chicago, University of Chicago Press, 211 p.

Harris, W. V. 1971. Termites: their recognition and control. London, Longman.

Hjarsen, T. 1997. Bird fauna and vegetation in natural woodlands and Eucalyptus plantations in the High Andes in Bolívia -implications for development of sustainable agroforestry techniques. Proceedings of the IUFRO Conference on Silviculture and Improvement of Eucalypts EMBRAPA, Colombo, p.8994.

Houston, T. F., B.B. Lamont, S. Radford \& S.G. Errington. 1993. Apparent mutualism between Verticordia nitens and $V$. aurea (Myrtaceae) and their oilingesting bee pollinators (Hymenoptera: Colletidae). Austral. J. Bot. 42: 369-380.

Hunter, M. L. 1990. Wildlife, forests, and forestry: Principles of managing forests for biological diversity. Englewood Cliffs, N.J., Prentice Hall, 370 p.

Janzen, D. H. 1974. The deflowering of Central America. Nat. Hist. 83: 49-53.

Jennersten, O. 1988. Pollination in Dianthus deltoides (Caryophyllaceae): effects of habitat fragmentation on visitation and seed set. Conserv. Biol. 2: 359-366.

Kearns, C. A. \& D.W. Inouye. 1997. Pollinators, flowering plants, and conservation biology. Bioscience 47: 297-307.
Lambeck, R. J. 1992. The role of faunal diversity in ecosystem function. In Biodiversity of mediterranean ecosystems in Australia. ed. R. J. Hobbs. p 129-148. Chipping Norton: Surrey Beatty and Sons.

Lamont, B. B. 1995. Testing the effect of ecosystem composition/structure on its functioning. Oikos 74: 283-295.

Liao Chong-Hui, Chen Mao-Qian \& Xie Ying-Shu. 1984. The initial investigation on soils animals in the tropical artificial forest of Xiaoliang (in Chinese). Trop. and Subtrop. For. Ecosyst. 2: 214-226.

Macedo, N. 1975. Estudo das principais pragas das ordens Lepidoptera e Coleoptera dos eucaliptais do Estado de São Paulo. Universidade de São Paulo, Piracicaba MSc thesis, Piracicaba, 87 p.

Majer, J. D. ed. 1989. Animals in Primary Succession: The Role of Fauna in Reclaimed Lands. Cambridge: Cambridge University Press, 547 p.

Majer, J. D., H.F. Recher \& N. Keals. in press. Canopy arthropod faunas in fragmented agricultural landscapes. In: Conservation of Australia's Temperate Woodlands. eds. C. Yates and R. J. Hobbs. Chipping Norton, Surrey Beatty and Sons.

Marinho, C. G. S., S.M. Soares \& T.M.C. Della Lucia. 1997. Diversidade de invertebrados edáficos em áreas de eucalipto e mata secundária. Act. Biol. Leopold. 19: 157-164.

Naeem, S., L.J. Thompson, S.P. Lawler, J.H. Lawton \& R.M. Woodfin. 1995. Empirical evidence that declining species diversity may alter the performance of terrestrial ecosystems. Phil. Trans. Royal Soc. London B 347: 249-262. 
Noss, R. F. 1990. Indicators for monitoring biodiversity: A hierarchical approach. Conser. Biol. 4: 355-364.

Noss, R. 1996. Conservation of biodiversity at the landscape scale, p. 574-589. In R. Szaro and D. Johnston (eds), Biodiversity in managed landscapes. Oxford, Oxford University Press.

Oliveira, M. A., T.M.C. Della Lucia, M.S. Araújo \& A P. Cruz. 1995. A fauna de formigas em povoamentos de eucalípto e em mata nativa no estado do Amapá. Act. Amazon. 25: 117-126.

Paton, D. 1996. Overview of the impacts of feral and managed honeybees in Australia. Canberra: Australian Nature Conservation Council, 71 p.

Paula, J. A. de 1997. Biodiversidade, população e economia: Uma região de Mata Atlântica. UFMG/Cedelplar, Belo Horizonte, 672 p.

Pavlik, B. M., N. Ferguson \& M. Nelson. 1993. Assessing limitations on the growth of endangered plant populations, II. Seed production and seed bank dynamics of Erysimum capitatum ssp. angustatum and Oenothera deltoides ssp. howellii. Biol. Conser. 65: 267-78.

Pedrosa-Macedo. J. H. 1993. Manual de pragas em florestas. 2. Pragas florestais do Sul do Brasil. Viçosa, IPEF/SIF, 111 p.

Pereira, J. M. M. 1992. Fauna de lepidópteros-praga de eucalipto em regiões de Minas Gerais e São Paulo. MSc thesis, Universidade Federal de Viçosa, Viçosa, 76 p.

Pirani, J. R. \& M. Cortopassi-Laurino. 1993. Flores e abelhas em São Paulo. São Paulo, EDUSP/FAPESP, 192 p.
Potma, H. L., S. Kengen \& M.R.A Alpande. 1976. Uma análise estatística da atual situação florestal brasileira. Brasília. Projeto Desenvolvimento e Pesquisa Florestal, $72 \mathrm{p}$.

Rathcke, B. J. \& E.S. Jules. 1993. Habitat fragmentation and plant-pollinator interactions. Current Science 65: 273277.

Recher, H. F. 1982. Pinus radiata - a million hectare miscalculation. Aust. Nat. Hist. 20: 319-325.

Recher, H. F., J.D. Majer \& S. Ganesh. 1996. Eucalypts, arthropods and birds: On the relation between foliar nutrients and species richness. For. Ecol. Manage. 85: 177-196.

Roubik, D. W. 1991. Aspects of Africanized honey bee ecology in tropical America. In The 'African' honey bee. ed. M. Spivak, D. J. Fletcher and M. D. Breed. pp 259-281. Boulder, Westview Press.

Saunders, D. A. \& R. J. Hobbs. (eds) 1991. Nature conservation 2: The role of corridors. Chipping Norton, Sydney, Surrey Beatty and Sons, 442 p.

Saunders, D. A., G. W. Arnold, A A Burbidge \& A J.M. Hopkins (eds). 1987. Nature conservation: The role of remnants of native vegetation. Chipping Norton, Sydney, Surrey Beatty and Sons, $410 \mathrm{p}$.

Saunders, D. A., R.J. Hobbs \& C.R. Margules. 1991. Biological consequences of ecosystem fragmentation: a review. Conserv. Biol. 5: 18-32.

Schoereder, J. H., M. Meguro \& W.B.C. Delitti. 1990. Efeito da substituição da cobertura vegetal natural na fauna de 
artrópodos de serrapilheira. Ciên. e Cult. 42: 76-78.

Showalter, T. D. \& J.E. Means. 1988. Pest response to simplification of forest landscapes. Northw. Environ. J. 4: 342343.

Silva, E. 1994. Avaliação qualitativa de impactos ambientais do reflorestamento no Brasil. Ph.D. thesis, Universidade Federal de Viçosa, Viçosa. 309 p.

Silva, E. 1996. Funções ambientais dos reflorestamentos de eucalipto. Inf. Agropec. 18: 5-7.

Silva, E. 1997. Impactos de eucaliptais sobre vertebrados silvestres. Proceedings of the IUFRO Conference on Silviculture and Improvement of Eucalypts EMBRAPA, Colombo, 150-153.

Sizer, N. 1994. Opportunities to save and sustainably use the World's forests through international cooperation. WRI issues and ideas. World Resources Institute, Washington, DC.

Tepedino, V. J. 1979. The importance of bees and other insect pollinators in maintaining floral species composition. In Great Basin naturalist memoirs. 3: the endangered species: a symposium. pp 39-150. Provo: Brigham Young University.

Vallejo, L. R., C.L. Fonseca \& A R. P. Gonçalves. 1987. Estudo comparativo da mesofauna do solo entre áreas de Eucalyptus citriodora e mata secundária heterogênea. Rev. Bras. Biol. 47: 363370 .

Viana, V. M., A A J. Tabanez \& J.L.F. Batista. 1997. Dynamics and restoration of forest fragments in the Brazilian Atlantic moist forest, p. 351-365. In. W F. Laurance and R. O. Bierregaard (eds.), Tropical forest remnants: Ecology, management and conservation of fragmented communities. Chicago, Chicago University Press.

Victor, M. A. M. 1977. O reflorestamento incentivado, dez anos depois. Silvicultura 1: $18-46$.

Vilela, E. F. 1986. Status of leaf-cutting ant control in forest plantations in Brazil, p. 399-408. In. C. S. Lofgren and R. K. Vander Meer (eds.), Fire ants and leafcutting ants: Biology and Management. Boulder, Westview Press.

Walker, B. H. 1992. Biological diversity and ecological redundancy. Conserv. Biol. 6: $18-23$.

Walker, B. H. 1995. Conserving biological diversity through ecosystem resilience. Conserv. Biol. 9: 747-752.

Waser, N. M. 1978. Interspecific pollen transfer and competition between cooccuring plant species. Oecologia 36: 223-236.

Waser, N. M., L. Chittka, M. V. Price, N.M. Williams \& J. Ollerton. 1996. Generalization in pollination systems, and why it matters. Ecology 77: 1043-1060.

Whelan, R. J. 1989. The influence of fauna on plant species composition. In Animals in Primary Succession: The Role of Fauna in Reclaimed Lands. ed. Majer, J. D. p. 107- 42. Cambridge: Cambridge University Press.

Williams, K. S. 1993. Use of terrestrial arthropods to evaluate restored riparian woodlands. Restor. Ecol. 1: 107-116.

Wilson, E. O. 1987. The little things that run the world (the importance and conservation of invertebrates). Conserv. Biol. 1: 344-346. 
Yen, A. \& T. R. New. 1997. Proceedings of the Conference on Invertebrate Biodiversity and Conservation. Memoirs of the Museum of Victoria 56, 675 p.

Zanúncio, J. C. 1993. Manual de Pragas em florestas. 1. Lepidoptera desfolhadores de eucalipto: Biologia, ecologia e controle.
Viçosa, IPEF/SIF, 141 p.

Zanúncio, J. C., M. A L Bragança, A. J. Laranjeiro \& M. Fagundes. 1993. Coleópteros associados a eucaliptocultura em regiões de São Mateus e Aracruz, Espírito Santo. Rev. Ceres 40: 583-589. 